\title{
The Arab College in Jerusalem 1918-1948: Influence of the Curriculum on the Cultural Awakening
}

Samir Hajj

Oranim Academic College and Beit Berl College

\begin{abstract}
This article seeks to shed light on the curriculum of the Arab College in Jerusalem established by the British Mandate Government in 1918. The curriculum of the college was similar to the educational program of an English public school and was overwhelmingly geared toward English language and literature, with special emphasis on British history, in addition to Arabic, Latin, geography, science, and mathematics. The curriculum was also geared toward teachers' training, in order to create a class of professionals to occupy managerial positions in the Mandate government and help in the administration of the country by working in schools, banks, and the Postal Service. This article examines and analyzes the curriculum of the Arab College, including textbooks and final examinations. It will also look at the role of the British Mandate Government in the improvement of the education system and the personal interviews with present graduates from the Arab College. It also examines the influence of the educational program on the writings of one of its graduates, Jabra Ibrahim Jabra (1920-1994). The literary works of Jabra, mainly in novel, poetry, and translation, represent an example on how the Arab College promoted the British culture among the Palestinian graduates of the college.
\end{abstract}

\section{Keywords}

Arab College; British Mandate; curriculum; Palestine; English culture

\section{Introduction}

Palestine was entrusted to Britain by the League of Nations in 1920. During the British Mandate, the social, economic, and educational development in the country had a decisive role in producing cultural revival. Contacts with Western culture were widened, and education was the initial impetus to this cultural revival. Most of the work in this field was a result of the development and improvement of the system of education by the Mandate Government. Hundreds of Palestinians who had received education in the newly established

\footnotetext{
* Samir Hajj, Beit Berl Academic College, Department of Arabic Language \& Literature, 4490500 Kfar Saba, Israel; samirfus@gmail.com
} 
schools were deeply influenced by English literature on the one hand and a variety of foreign cultural influences on the other. The British Mandate established the Arab College as a pilot school with high academic standard for the elite, eventually providing an educational program similar to an English public school education. The curriculum of the Arab College contributed to the general change in attitude toward literature and the revival of Palestinian culture. Some of the graduates of this college were educators, others civil servants, and a few reached high positions in the Mandate Government. Others continued their studies in British universities.

This study discusses the establishment and development of the college; its system of education; the curriculum, methods of teaching (including textbooks), and examinations; and the influence of curriculum on the graduates. It sheds light on how the curriculum of the Arab College, which was overwhelmingly geared toward English language, literature, and history, created a class of professionals to help in the administration of the country and the cultural revival, as demonstrated in the personal interviews with graduates from the Arab College. It examines the influence of the educational program on the writings of one of its graduates, Jabra Ibrahim Jabra (1920-1994). The literary works of Jabra, mainly in novel, poetry, and translation, represent an example of how the Arab College promoted the British culture among the Palestinian graduates of the college.

\section{Establishment and Development of the College}

The college was founded in March 1918 in Jerusalem by the British military administration in Palestine that preceded the British Mandate Government (Barghuthi and Totah 2001, 261) under the name Teachers Training College. In 1927, a new name was given to the Teachers Training College, and it became known as the Arab College. From its inception in 1918 until 1934, the college was run in rented buildings in the neighborhood of Bab al-Sahira in Jerusalem; then it moved to a new location on Mount Scopus (Jabal alMukaber). The college was initially a school for preparing and training teachers for primary schools and some secondary school classes. It started with 23 students, all of them were Arabs, with the exception of one Jewish student (whose name was not disclosed), but the writer of this article was able to find out that this student was Israel Ben-Zeev (1899-1980), nicknamed Wolfensohn (Abu Dhu'ayb in Arabic).

In the first period, Egyptian, British, and Iraqi teachers taught at the college; among them is the well-known Iraqi poet Ma'rūf Abdul Ghanī Rașāfī (18751945). In terms of curriculum and teaching textbooks, the college used the 
textbooks prepared in Egypt (Dajānī 1990, 99) by British authors. In fact, the Mandate Government used in Palestine the same educational syllabus prepared for British colonies in Africa, mainly in Egypt. In Egypt, more than one-fourth of the educational program was dedicated to teaching English and foreign languages. English, in general, was the primary language in public schools (Matthews and Akrawi 1950, 59).

The contact between the Egypt and Western civilizations began with the campaign of Napoleon Bonaparte (1769-1821) in 1798, when the Egyptian intellectuals came in close contact with the European culture. The contact and influence of the Western culture on Egypt increased in the period of Mohammed Ali Pasha (1769-1849), who ruled over Egypt for a long period (1805-1848). He worked on the establishment of a civil education system and a modern Islamic state. There were not $>200$ persons who could read and write when he came to power (Haridi 2006, 276). Therefore, he was concerned with the establishment of modern schools and on sending Egyptian students on scientific missions to study in Europe, mainly in Italy and France. The Egyptian scientific missions continued to flock to Europe, in the period of Ismail Pasha (1830-1895), who ruled Egypt for a short period (1863-1867). Ismail was sent to Europe during his youth in one of the missions. However, after the British occupation of Egypt in 1882, the Egyptian government started to send its scientific missions to Britain. Conversely, the situation in Palestine was different. At the beginning of the twentieth century, Palestine was a province of a declining Ottoman Empire and suffering from poor administration. It was in a state of isolation from the intellectual and cultural movements in the Arab World and the West. Palestine, however, witnessed a significant educational revival after the start of the British Mandate period. The Arab College that was established by the British was the first boarding secondary school and the only public secondary school with inclusive classes where students could study for 4 years. The top students who had completed primary school in the cities, towns, and villages were selected to attend the college to prepare them to become teachers.

\section{The System of Education in the College}

The Arab College was established as a teachers training college with the aim of preparing elementary school teachers. However, in 1925, it was decided that it should assume the responsibility not just of training teachers but also of preparing students to pass the Palestine Matriculation Examination. Beginning with the summer of 1926, this general examination was given to students who had completed secondary school and wished to continue 
their university education outside Palestine. According to this development, the college began to focus on academic subjects that were covered in the Matriculation Examination. In the same year, the college introduced a fifth secondary grade to train teachers chosen from among those who passed the Matriculation Examination. In this class, the student learned important academic subjects, such as Arabic, English, and history, with emphasis on practical and theoretical educational material such as history of education, psychology, and teaching methodology. The system of education continued this way until 1939, when an important change took place in the development of the Arab College. Beginning with the third secondary grade, the lowest grade in the college, students were streamed into two divisions, namely, science and art. Then a sixth secondary grade was added in which the students sat for the Palestine Intermediate Examination, which qualified them to teach in the primary and early secondary levels.

As the system of education in college started with the third and fourth secondary classes, the study in some schools in Palestine ended with the seventh grade in the primary education. Therefore, it was not possible for those students to register in the Arab College (Khalidi 1992, 53). Therefore, they studied the first and second secondary classes in the Rashidiyah College before joining the Arab College. This is what happened with the Palestinian writer Jabra Ibrahim Jabra (1920-1994). He finished his second secondary class in the Rashidiyah College in 1935, and then he moved to The Arab College.

At the beginning of its establishment, the Jerusalem College gave students not only free rooms (Najm 2007, 126), board, and tuition but also pocket money. Later, the college charged 8 Palestinian pounds per semester, or 24 pounds per year (in 1927, the Mandate Government coined the Palestinian pound, which was equivalent to the English pound). However, in practice, waiver of tuition fee was the rule because the majority of the students were academically distinguished or were poor. Some authors have felt that the goal of the British Mandate in founding the Arab College was to create a class of educated people to occupy managerial positions in the Mandate Government and help in the administration of the country by working in schools, banks, and the Postal Service (Khalidī 1991, 41).

The best male students who excelled in the different schools in the Palestinian towns and villages were selected and enrolled in the Arab College. The academic program followed an intensive teaching of the English language similar to the system used in Eton College in Britain; a school characterized by being for discerning male students who were between the ages of 13 and 
18 years. All of this was in order to nurture a new generation saturated with English culture because students studied seven classes per day, five classes before noon and two after lunch, 6 days every week mainly in English, while they were studying fewer classes in the Arabic language (Najm 2007, 156).

In fact, until 1908, the Ottoman government had neglected educational services in Palestine. Facilities for education were nonexistent in villages and very rare in towns. However, the role of schools in the Ottoman period until the outbreak of World War I in 1914 was limited to teaching the Quran, Arabic language, history, geography, and mathematics (Tibawi 1956, 77). Therefore, the Department of Education in the British Mandate followed a new curriculum similar to the British system of education. The Mandate government wanted to show the Arab population that they are improving the level of education. They established the Teachers Training College, which started as a school for the training of teachers for lower grades in elementary and secondary classes, and then it turned into a college, which prepares its graduates for the Matriculation examination in order to be able to be admitted in the British universities. Therefore, most of the attention was focused on the English language, and the academic body for this subject consisted of wellqualified international teachers, mainly from England, in order to be taught this language at the hands of native speakers (Najm 2007, 156). The other subjects were also taught with well-qualified teachers, who were graduates of the best universities of the time.

In the early years of the establishment of the college, specifically in 1920, the illiteracy rate in Palestine was up to $90 \%$ and it was more than that in the villages, because the Palestinian society was predominantly composed of peasants. However, most of the work in the field of education during the Ottoman period was a result of private initiative: a large number of missionary and sectarian schools were founded in the second half of the nineteenth century because of the growing interest shown by several Western countries in the Holy Land. It is interesting to note from reading the names and addresses of the graduates of the Arab College, starting from the early years of its opening until 1948, that the vast majority of the graduates among those who received the Matriculation Certificate, the Secondary School certificate, or the Intermediate Certificate were from the urban population, particularly from Jaffa, Jerusalem, Tulkarem, Hebron, Nablus, Bethlehem, Gaza, Lod, Nazareth, Tiberias, Acre, and Haifa (Najm 2007, 219-296). This conclusion applies to all years starting from the foundation until the closure of the college. In 1928, e.g., the number of successful candidates in the Matriculation Examination was 12, nine of whom were from urban areas. 
The number of graduates in the Intermediate Certificate was eight, including seven students from the cities (Najm 2007, 219-220).

On the other hand, the lack of public schools or inclusive schools in the villages, in addition to the difficult economic situation at that time, especially in the period between World War I and World War II, prevented the enrollment of students from the villages in this educational institution. Furthermore, the then-exorbitant tuition fee, which was 24 Palestinian pounds, in addition to travel and accommodation expenses, was an obstacle for the enrollment of many of the villagers. For these reasons, education was limited in its majority to the inhabitants of the cities. However, I do not agree with the view that secondary education for Arabs in public schools was limited to the elite and the middle or upper class (Matthews and Akrawi 1950, 246), because the Palestinian community during the British Mandate was predominantly composed of peasants, and there were no classes according to the modern concept, except a small number of notables and landowners. The number of teachers who graduated from the college was not enough to meet the needs of schools in Palestine. It was $<20$ teachers per year, and this number was not enough for all the towns and villages in Palestine. This led the Department of Education to either appoint nonqualified teachers or not open new schools or classes.

The illiteracy rate remained very high, especially in the villages due to the lack of schools. This was indicated in the report of the Palestine Royal Commission in 1937: "Among the children who are of school age, which is estimated at nearly 260,700 boys, only 42,700 boys are taught in the government schools now. The Arab observers estimate that $85 \%$ of the peasants are still illiterate" (Palestine Royal Commission 1937, 119). The illiteracy rate has not declined significantly, from what it was at the end of the Ottoman rule, because in 1920, the rate of primary and secondary school students among the Arab population formed $2.7 \%$ of the total population. The total number of the Arab population was 600,000 inhabitants (Nashwan 2003, 76) and the total number of students was 662.10 (Nardi 1945). However, the British Mandate Government claimed to have developed education in Palestine. It was mentioned in the Report of the High Commissioner, Herbert Samuel (1920-1925) that the Mandate Government had established 190 schools in $<3$ years:

There is great interest in the Education Department. The Arabs are witty people and have now realized the degree of their backwardness because of illiteracy. Therefore, they started with great passion the establishment of schools, not only in the cities but also in villages, too. They have shown their passion by giving willingly large amounts of 
money to establish schools. The government announced in December 1920 that it is ready to cover the expenses of a number of schools in the village if the villagers offered the necessary buildings, thus leading to a strong rivalry to find these schools and in less than three years, 190 schools were established. It was possible to increase this number critically. However, the financial situation forced us to stop working in this program. (Report of the High Commission, 11-12)

However, the number of schools established during the period of Herbert Samuel (1920-1925), according to many scholars, did not exceed 144 (Najm 2007, 111).

\section{The College Director}

There is no agreement among the different sources on the identity of the first Arab director of the college. Some references say that 'Adel Jabr (1885-1953) was the first person to assume the role of the director of the college (Nuwehid 1981, 64). Other sources indicate that Khalil as-Sakākinī (1878-1953) was appointed on September 10, 1919, as the first director (Khalidī 1992, 136). In the meantime, Nicolā Ziyadeh says that the first director of the college was an Egyptian teacher at the college from the Jamal family (Najm 2007, 71). However, the writer of this article supports the view that Khalil as-Sakākinī was the first director of the college, because of his British cultural background and because he was a member of the British Mandate Department of Education in Palestine. However, soon after his appointment, Khalil asSakākinī resigned on June 23, 1920, to protest the British appointment of the Jewish Herbert Samuel (1870-1963) as the High Commissioner of Palestine (Sakākinī 2006, 223). After the resignation of Sakakini, Dr. Khalil Tūtaḥ (1887-1955) was appointed as director of the college (Najm 2007, 71; Ziyadeh 2005). He was the college's headmaster until 1925 . He too resigned following protests by administrators, teachers, and students against the visit of Arthur James Balfour (1848-1930) who came for the inauguration of the Hebrew University. Khalil Țūtah did not take any position in this regard, which led to his resignation from the administration of the college (Abidi 1974, 26). Some sources say that he was dismissed by the Department of Education of Palestine (Khalidi 1991, 41) on October 16, 1925. Then, the general director of education in Palestine, Humphrey Bowman, called on Aḥmad Samih alKhalidī (1896-1951) to run the affairs of the college. He continued to do so until the end of the mandate in 1948. The appointment of Khalidi was a turning point in the college's history. The Arab College had become the most prestigious school for Arab students in Palestine during his administration. 


\section{College Tasks}

The role of the Arab College can be summed up in two functions, as mentioned in the speech of its director Ahmad Samih Khalidī on July 15, 1933:

Preparing and training qualified teachers to take the responsibility of teaching in the higher classes of the primary schools in the towns and villages after they complete their secondary education; provide an excellent and limited group of intelligent young Arabs with liberal education entitling them with the knowledge they gain in English to pursue their education and studies in the most prestigious universities in Europe, America and the East (Khalidi 1992, 50).

In fact, the Mandate Government felt the need to prepare eligible graduate students to continue their academic studies in European and American universities in general and the British universities in particular. This is similar to what was done in Egypt during the reign of Muhammad Ali Pasha, when the Egyptian government sent many students on scientific missions to French universities.

When the Teachers Training College was founded, the enrollment was done based on success of the student in the entrance examination. Students must have also reached 15 years of age. However, when Khalil Țūtạ̦ became director of the college, he followed a new system under which only the best and the brightest Palestinian students attended the college. These students were chosen for their intellectual, moral, and academic abilities, from among those students who had completed the first phase of the primary studies in every public school in Palestine (Udat 1992, 146). A committee composed of the headmaster of their school and one or two officials from the Department of Education would conduct personal interviews with the selected students in order to determine their qualification for the teaching profession.

The study at the elementary school in Palestine, consisted of 6 years, then it increased to 7 years. The study at the Secondary School was in two phases; the first phase included the first and the second secondary grades, and the second phase included the third and fourth secondary grades (Abassi 1992, 62-66), at the end of which the students were given the Matriculation Certificate. The Arab College was considered as a higher education institution because it provided the student with 1 or 2 years of training after the Matriculation certificate. The college was distinguished from the rest of the secondary schools by its high scientific standard and its selected students. The number of secondary classes in all government schools in Palestine, including the Arab College, for men and women between 1929 and 1930 was 25 classes, which 
included 353 students. The total number of pupils in all primary schools in the cities was 9529 students (Tibawi 1991, 47).

The program of the college developed into a higher stage called the High Level, when it started the system of Intermediate Examination at the end of 1941. Three different diplomas existed at the college, each representing a different scientific level (Abbasi 1992, 66). These diplomas were as follows:

1) The Palestine Matriculation: the examination was conducted under the supervision of the Council of Higher Education and administered by the general director of British Department of Education.

2) Palestinian Education Diploma: the students were streamed into two divisions, scientific and literary. Students in the scientific stream learned theoretical and applied mathematics, while their literary counterparts studied the hallmarks of an English liberal education: philosophy, classical history, Greek, and Latin.

3) Palestinian Intermediate Diploma: after the sixth secondary grade, the students sat for the Intermediate Examination, which qualified them to teach in the primary and early secondary levels.

Hashim Yaghi, one of the graduates of the Arab College, believes that the British Mandate Government was serious about improving education in Palestine, through the establishment of the Arab College, which was a pilot school with high scientific level. He explains this by saying, "It may be one of the reasons for the establishment of the college is to avoid the criticism of the Mandate by the Arabs, because the British allowed the Jews to administer their system of education. Therefore, the establishment of the Arab College came within the specifications that we talked about repeatedly" (Khalidi 1992, 44). In my view, the establishment of the Arab College as a pilot college stems from their vision, expressed in the poem of Rudyard Kipling "White Man's Burden", that the white European man has an important mission in the dissemination of culture and education to other races.

\section{Curriculum and Methods of Teaching in the Arab College}

A survey of the teaching program at the Arab college shows the context that influenced teaching as well as what was taught and how it was taught. The Arab College was initially an institute for teachers training; therefore, special attention was given to the subject of psychology, teaching methods, and classroom management. Later, the Arab College evolved from an institution geared solely toward the training of teachers to an academic establishment for the elite, eventually providing an educational program similar to an English public school education. Students in the scientific stream learned theoretical and applied mathematics, while their literary counterparts studied 
the hallmarks of an English liberal education: philosophy, classical history, Greek, and Latin. A survey of the English literature-teaching program will give us an idea about the nature and content of the curriculum.

In English literature, the curriculum covered the different periods, schools, and trends. The students were taught most of the plays of William Shakespeare (1564-1616), mainly Hamlet, Macbeth, The Merchant of Venice, Julius Caesar. King John, King Henry II, King Henry IV, and King Henry V. In poetry, the book of A. A. Mendilow and Dorothee Metlitzky, entitled Essential Poetry (Aronson 1942), was used for teaching. It included selected poems of the most important English poets, with their biographies, starting from the seventeenth century until the end of the nineteenth century. These poems reflected different periods of English literature. It included poems of John Dryden (1631-1700), John Milton (1674-1608), Alexander Pope (1688-1744), Thomas Jerry (1716-1771), William Blake (1827-1757), Samuel Coleridge (1772-1834), Lord Byron (1788-1824), Percy Shelley (1792-1821), John Keats (1795-1821), Lord Tennyson (1809-1892), Robert Browning (1812-1880), and Matthew Arnold (1822-1888).

From the above, we conclude that the Arab College focused extensively on teaching English literature in its various forms, and the curriculum reflected different periods, trends, and schools of English literature. However, the Department of Education did not make any effort to write and publish special books for teaching English to Palestinian students. They used books that were specially prepared for teaching students in India and Pakistan. However, for teaching Arabic language and literature, the Arab College adopted books written by Egyptian authors such as Ali Jārim (1881-1949), Țaha Hussein (1889-1937), and Musțafa Amīn (1914-1997) (Dajānī 1990, 79). Nevertheless, most literary texts were taken from classical literature, unlike the English texts, which reflected the different periods and different literary genres.

In fact, the educational curriculum in the college was changing according to the development of the college. In 1925, the Arab College was entrusted with another task besides the training of teachers for the elementary and the secondary stages. The new task was to prepare graduate students qualified to enter universities abroad, by sending scientific missions in order to return as administrators and teachers in the Mandate Government (Khalidī 2000, 137). Four years enabled the students to present themselves for the Matriculation Examination in Palestine, while a fifth year was dedicated to the training of teachers (Qatshan 1987, 177). Due to this development, the college began to focus on the academic subjects covered in the Matriculation Examination. In 
the academic year 1938-1939, a second year was added after the Matriculation, and the period of teaching became 6 years: 4 years of secondary education and 2 years for the teacher training. After Matriculation, the student chose to specialize in one of the subjects, such as mathematics, science, Arabic language, English, philosophy, or the Latin language. The student was able, at the end of the sixth year, to pass the Palestine Intermediate Examination and the University of London Intermediate Examination.

The principal of the elementary school in 'Iblin in Galilee, the late 'Abdu Mubada Salim (1927-2010), was one of the graduates of the Arab College. He passed the Intermediate Diploma Examination in 1946 (Najm 2007, 291). He told me in an interview that the Arab College relied mainly on the quality of students, not the teachers. In fact, teaching was based on memorization and indoctrination; however, the secret of the success of the college was due to the diligence and intelligence of its students.

The Palestinian scholar Amin Hāfez ad-Dajāni argued as follows:

The aim of this curriculum was to obliterate the Arab national identity and educate this generation about the Western civilization, English Literature and culture, disregarding the history, geography of the Arab countries and their literature and heritage, in order to make the student feel proud of the English history and all what is English. I can say that the student knew about Britain, its history and literature more than the British themselves did (Dajānī n.d., 77).

In fact, there is a lot of subjectivity and exaggeration in this point of view, because Dajani puts the full responsibility on the British and exonerates the Arabs of their duty and their role in educating their children and establishing educational institutions. Some Arab nationalists portrayed Latin and the British liberal education in general as an alien imposition that diverted the best and the brightest away from service to their nation. However, Jerome Farrel in the Department of Education of the British Mandate, like the eminent Arab writer Taha Huseein, see the institution of Latin in the curriculum of the college as part of the legacy that actually brought Arab civilization to Europe (Falb 2013, 53-71). Latin language and literature was one of the subjects taught at the college because Latin literature included poems, plays, letters, and articles written by ancient Roman authors full of rhetoric, an art of discourse that aims to improve the capability of the students to speak and persuade particular audiences in specific situations.

Conversely, one cannot ignore the fact that the Arab College included prominent students and teachers and was considered by the national leaders an appropriate place for the dissemination of political ideas. The Arab College 
produced students who did not accept British educational methods due to any love for the British; rather, those methods justified their belief in themselves and their view of themselves as leading their generation by intellectual merit. Many graduates of the college rejected British political policies and later occupied important positions. Among the most well known in the literary field, we can mention Jabra Ibrahim Jabra (1920-1994), Ih san 'Abbas (19202003), Tawfiq Sayegh (1923-1971), H̦annā Abu H̦annā (born 1928), Nasir ad-Din al-Assad (born 1923), Nicolā Ziyadeh (1907-2006), Mahmūd asSamra (born 1923), Mahmud Ali Ghūl (1923-1983), Muhammad Yūsuf Najm (born 1925), 'Abdul Raḥmān Yāghi (born 1924), and Hāshim Yāghi (born 1921).

During this period, contacts with Western culture were widened: hundreds of Palestinians who had received education in the humanities in the Arab College in Jerusalem and in Western universities became writers with varied viewpoints and interests. In addition to their cultural pursuits, they were actively engaged in practical and administrative tasks. Some of them were educators, others civil servants, and a few reached high positions in the Mandate Government. Their writings reflected their role as community leaders and public representatives: they wrote extensively about reform in the system of education, the taxes imposed on the farmers, the Balfour declaration, and the dangers threatening their homeland. These intellectual leaders were later the most outspoken critics of mandate authorities. They kept alive the national consciousness through the literature they wrote during this period. This literature manifested itself in many channels: in a flourishing press, in literary societies that became the cradle of political nationalism, and in scholarly writings about language, literature, and history. The newspaper column became the chief medium of expression for writers. Short pieces took a variety of literary forms and included articles, poems, short stories, and political tracts. Newspapers became the most important forum for literary expression during the British Mandate period. The tradition of membership in literary societies continued during the mandatory period, playing a noteworthy role in developing the cultural life of the country.

During the British Mandate period (1918-1948), a new generation of writers came forward who not only knew Western literary theories but also were able to relate them to their own work. These writers derived their inspiration mainly from the Romantic Movement. Themes of major concern to the ordinary people began to replace the classical themes. We witnessed also the development of drama, the novel, and the short story. The classicists opposed the new movement, claiming that it was an imitation of the West. They 
accused the new writers of undermining tradition, not only by playing with metrical laws and the one-rhyme scheme in the language of poetry but also by introducing themes and symbols that were alien to the spirit of Arabic tradition. The modernists saw that the classicists did not perceive the necessity of breaking away from past literary conventions, although they lived in the new age.

Among the main representatives of the modernists were the graduates of the Arab College. On the one hand, they were influenced by both the direct contact with the British cultural influences in the Arab College as well as studying in British universities. On the other hand, the modernists were familiar with the contributions of Egyptian cultural leaders and were heavily influenced by their readings of Arabic romantic poetry and criticism. Short stories written in this period pointed out an obvious moral related to social and ethical questions, and romantic poetry spread with amazing speed. The main contribution of Khalil Sakakini in this period lies in the innovativeness of his prose style. In his numerous articles about the Arabic language and literature (as in his book Readings in Language and Literature, 1925), he showed his inclination toward the romantic school. Since he was the principal of the Teachers' Training College in Jerusalem and an inspector in the Palestine Department of Education for many years, his influence on his students and colleagues was very important. Another figure who witnessed a new type of literature, marked by tension between a relatively classical style and the new scientific style, was Ishaq Musa al-Hussieni, manifested by the influence of scientific methodology in his research as well as the influence of the British Orientalist Gibb.

During the forties, the literary movement simultaneously developed into two main schools: romantic and realistic. The realistic school was in favor of a greater involvement of literature with social problems. A number of writers became aware of the social and political message of literature as a reflection of the pressing needs for political action to save their land. On the other hand, the romantic school formed a strong opposition to the realistic. Its followers believed that literature is a unique linguistic expression of an individual vision and that it is primarily self-exploration. According to them, any form of commitment directly preached is harmful to art and distorts its nature. Al Irani (1914-1974) was a typical representative of many Palestinian critics of the period who were exposed to a great variety of influences. He was deeply impressed by Western, particularly with English and French, literature. He was a powerful writer, a brilliant essayist who wrote in the leading newspapers of the day. By the end of the forties, the influence of Western critical theories 
contributed to the development of new literary genres. It produced a literature with a more coherent and lucid perspective and direction, with a soundly formulated criticism.

\section{Specimen of the College Examinations and the Influence of Curriculum on Graduates}

This expansion in the teaching of European literature in general, and English literature in particular, points out that the policy of the British Mandate Government was to educate and develop a generation in Palestine influenced by English literature and culture. This appears very clear in the specimens of the final examinations. We find clear interest in teaching English literature in the examinations of the Palestine Intermediate Diploma for the year 1932. The English literature examination included three sections: the first and the second sections consisted of 12 questions, and the third section consisted of 13 questions. The examination contained questions on literary criticism, poetry, drama, and novel. Students were asked also to make an analysis and generate conclusions of their analysis. Here are a few examples:

Question no. 4: What is the difference between the critical theories of Matthew Arnold, Hazlitt, and Lamb?

Question no. 5: Is it possible to claim that Shelley is the main lyricist today?

Question no. 7: What are the innovative aspects in the novels of Scott?

Question no. 9: Write a critical description of the short poetic works of Browning (Final Examination for the Palestine Diploma, July 1932).

The second section revolved around the works of William Shakespeare; the third section was about drama, prose, and poetry of Milton and the influence of the Middle Ages on his work (Final Examination for the Palestine Diploma, July 1932).

One of the graduates of the college explains the emphasis on the teaching of English literature as follows:

I entered the Arab College in 1937, and I received, in 1939 the Matriculation certificate. In 1941, I completed the requirement for the Intermediate Diploma. Until today, I still remember the Paradise Lost, the Tempest and the Rivals. In addition to the different periods and schools in English literature. The plays of Shakespeare, for example, were given to us in 1937. We studied The Merchant of Venice during the class of the Matriculation, while in the Intermediate Diploma we studied Milton and Gibbons, a famous historian who wrote The Rise and Fall of the Romanian Empire; one of the most complex texts in the English language. Q: All this in English? A: Yes, as well as we were 
asked to make additional readings in the library. In addition to classes in Latin language. Professor Hourani gave us lectures on the history of Greece (Abbas 1992, 174).

This influence of teaching English literature appears very clear in the works of the Palestinian writer Jabra Ibrahim Jabra (1920-1994), who finished his studies at the Arab College in 1937 (Najm 2007, 253) and then continued his studies at British universities. He says about his trip in 1939 on a ship to Britain on a study mission:

I was nineteen years old the day I arrived to Port Sa'id, after a long night journey on the train from the city of Jaffa. It was the first time that I leave my country. Our trip to England was organized through the Thomas Cook office by the Department of Education. I was with two other students: Hilmi Samara who was about two years younger than I was, and Hamid 'Attāri who was three years older than me. We are all graduates from the Arab College of Jerusalem, this amazing institution in which the Department of Education assembled young talented students from the government schools in Palestine, most of them were fifteen years old. We studied two or three years on the hand of competent professors under the supervision of the dean Ahmed Samih al-Khalidī who is one of the most prestigious intellectuals in Palestine. We were prepared to become teachers or to be sent in missions to the American University of Beirut or a university in England - at the time no universities for Arab students in Palestine (Najm 2007, 253).

In Britain, Jabra attended the University of Exeter in the first academic year (1939-1940) to study English literature. He completed a Bachelor of Arts degree in 1943 and the Master's degree in English literature at Cambridge University. He still remembers the names of poets he studied while he was in Britain: John Dryden, Alexander Pope, William Wordsworth, Samuel Coleridge, Percy Shelley, John Keats, and Matthew Arnold. He studied these same poets during his enrollment at the Arab College. Jabra represents an example of a Palestinian intellectual saturated with English culture, because of his studies at the Arab College. This explains why he wrote some of his novels and poems in English. One of these novels is Hunters in a Narrow Street (Heineman 1960).

Jabrā also was influenced by the English-American poet Thomas Eliot (18881965), especially his free verse, his metaphoric mode of representation, and his mythical method in the Waste Land (1922). Eliot created in this poem new forms and filled it with rich complex symbols, ambiguity, and intertextuality. Eliot, according to Jabrā, is "a model for my generation of students at Cambridge University, he is an integrated poet and critic; he fascinated me from the beginning" (Jabrā 1992, 25). Jabrā translated 26 books of the most 
prominent Western writers from English into Arabic. The translated works of Jabra, his introductions to these translations, and other studies he wrote about Western literature influenced modern Arabic literature. He introduced the polyphony and stream-of-consciousness narration into the Arabic novel and influenced modern poetry in terms of technique and style, the use of pagan, Greek, and Christian symbols and legends. A look at the titles of the most important books he translated shows the important influence of Jabrā on modern Arabic literature. These books are listed below according to the date of publication in Arabic:

James George Frazer. Adonis: Studies in the History of Oriental Religion, 1957

Henry Frankfort et al. The Intellectual: Adventure of Ancient Man, 1960 William Shakespeare. Hamlet Prince of Denmark, 1960

Lawrence Roger Thompson. Robert Frost: The Early Years 1874-1915, 1960

William Van O'Connor. William Faulkner, 1960

W, Roy Cowden. The Writer and his Craft, 1962

William Faulkner. The Sound and the Fury, 1963

Eliot, Alexander. Sight and Insight: Afar al-Fan, 1964

Norman Forster. Ed. American Poetry and Prose, 1966

Samuel Beckett. Waiting for Godot, 1967

Germaine Bree. Albert Camus, 1968.

Eric Bentley. The Life of the Drama, 1968

William Shakespeare. King Lear, 1968

Bernice Slote. Myth and Symbol: Critical Approaches and Applications, 1973

William Shakespeare. The Tragedy of Coriolanus, 1974.

Edmund Wilson. Axel's Castle: a Study in the Imaginative Literature of 1870-1930, 1976.

William Shakespeare. The Tempest, 1979.

Jann Kott. Shakespeare Our Contemporary, 1979.

William Shakespeare. Macbeth, 1980.

John Dover Wilson. What Happens in Hamlet? 1981.

Charles Brian Cox. Dylan Thomas: a Collection of Critical essays, 1982.

William Shakespeare. The Sonnets, 1983

William Shakespeare. Tragedy of Othello, 1986.

Janette Dillon. Shakespeare and the Solitary Man, 1986. 
September without Rain and Other Stories. Translated and Introduced by Jabra Ibrahim Jabra, 1986.

Tales of La Fontaine. Translated and Introduced by Jabra Ibrahim Jabra, 1987.

Oscar Wilde. The Happy Prince and Other Fairy Tales.

As seen in this list of Jabrā's translations, there is a special attention given to the translation of the works of drama, sonnets of Shakespeare, and important studies about him. The translation of several plays for Shakespeare, known for their difficult and complex language and poetic style, is a proof of Jabrās capacity and competence in English language and literature because of the intense educational program at the Arab College.

\section{Conclusion}

From the above considerations, we conclude that the cultural revival in Palestine was determined, on the one hand, by a multitude of internal factors; however, education was the initial impetus and the most important factor. On the other hand, the best scientific and literary thoughts of the West were disseminated in the curriculum of the Arab College, which focused extensively on teaching English literature in its various forms, reflecting different periods, trends, and schools of English literature. The college included prominent students and teachers and was an appropriate place for the dissemination of contemporary ideas; it could be said that it was the most effective tool in the cultural revival in Palestine. In fact, the greatest sources of inspiration of Palestinian culture in the twentieth century did not originate from classical Arabic literature but from the contact with Western culture. The literary revival was a gradual product of the confrontation between the traditional values of Arabic language and literature and the modern critical values of the West.

\section{References}

Abassi, Mohammad. 1992. القدس الشريف [“The Arab College in Jerusalem”]. Al-Quds al-Sharif 84: 62-66.

Abbas, Fu’ad. 2000. الكلية العربية في القد 1948-1918 ذكريات ["The Arab College in Jerusalem 1918-1948”]. Memories. Palestine Studies Journal. 42: 168-175.

Abidi, Mahmud. 1974. الكلية العربية في القدس [“The Arab College in Jerusalem”]. Islamic Quarterly Vol 18, 1-2, January-July.

Barghouthi, Oma and Khalil Totah. 2001. تاريخ فلسطين [History of Palestine]. Port-Sa'id: Maktabat al-Thaqafa ad-Dinyiah. 
Dajānī, Amīn. n.d.. جبهة التربية والتعليم ونضالها ضد الاستعمار 1948-The Education Front and its Struggle against Colonialism 1918-1948”]. Memoranda Prepared by the Government of Palestine. London: 1,207.

“The Brit- الانتداب البريطاني والعهد الأردني والاحتلال الإندرائيلي والسلطة الوطنية الفلسطينية .1990 ـ- ish Mandate, the Jordanian Period, the Israeli Occupation and the Palestinian National Authority"].

Davis, Rachelle. 2003. "Commemorating Education: Recollections of the Arab College in Jerusalem, 1918-1948." Comparative Studies of South Asia, Africa and the Middle East 23, no. $1 \& 2: 190-204$

Falb, Hilary. 2013. "Pedagogical Paradox Education and Internationalization in the Mandates of Palestine and Mesopotamia." KUFA Review 2, no. 3: 53-71

Haridi, Salah. 2006. 1805-1882 دراسات في تاريخ مصر الحديث المعاصر [“Studies in Modern Egyptian History 1805-1882”]. Cairo: 'Ein for Studies and Research in Humanities.

Jabrā, Jabrā Ibrahim.1992. معايشة الذمرة وأوراق ILiving with the Tigress and Other Papers]. Beirut: al-Mu asasah al-'Arabiyya lid-Dirasă wan-Nashr.

- 1999. 19 . شارع الأميرات: فصدل من سيرة ذاتية [The Street of Princesses: Chapters of a Biography]. Beirut: al-Mu asasah al-'Arabiyya lid-Dirasăt wan-Nashr.

Jordan, Winthrop. 1974. The White Man's Burden. London: Oxford University Press.

Khalidī, Walīd. 1991. القصة الكاملة للكلية العربية المقدسية منذ تأسيسها كدار للمعلمين ["The Complete Story of the Arab College in Jerusalem1919-1948”]. Al-Quds al-Sharif78: 40-58

["The Arab College in Jerusalem”]. Al-Quds al-Sharif 82: 45-62.

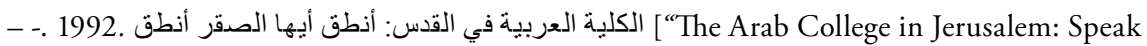
O Falcon"]. Al-Quds al-Sharif 88: 39-47.

- " 1992. الكلية العربية في القدس .The Arab College in Jerusalem”]. Al-Quds al-Sharif 90: 51-61.

Matthews, Roderic and Matta Akrawi. 1950. Education in Arab Countries of the Near East. Washington, D.C: American Council of Education.

Najm, Muhammad. 2007. دار المعلمين والكلية العربية في بيت المقدس [The Teachers' College and the Arab College in Jerusalem]. Beirut: Dar Sader.

Nardi, Noah. 1945. Education in Palestine 1920-1945. Washington D.C: Zionist Organization of America.

Nashwan, Omar. 2003. التعليم في فلسطين مذذ العهد العثماني وحتى السلطة الوطنية الفلسطينية (Education in Palestine from the Ottoman Period to the National Palestinian Authority]. Gaza: Persa.

Nuwehid, Ajaj. 1981. رجال من فلسطين [Men from Palestine]. Beirut: Occupied Palestine Publication.

Palestine Royal Commission. 1937. Memorandum prepared by the Government of Palestine. London.

Qالتعليم العربي الحكومي إبان الحكم التركي والانتداب البريطاني 1948-1516 1516. [The Arab Public Education during the Ottoman and British Mandate Period 1516-1948]. Amman: Dar al-Karmel as-Samed. 


\section{Journal of Nationalism, Memory \& Language Politics 11(1)}

Report of the High Commissioner on the Administration of Palestine 1920-1925. Jerusalem: Greek Orthodox Monastery. 11-12

Sakākinī Khalil. 2006. بوميات خليل السكاكيني: بوميات، رسائل، تأملات [Diaries of Khalil Sakakini: Letters and Contemplations]. Ramallah: Jerusalem Studies Institution

Sawafiri, Kamel 1979. لأدب العربي المعاصر في فلسطين [The Modern Arabic Literature in Palestine] Cairo: Dar al-Marif, 1979.

Tibawi, A. L. 1956. Arab Education in Mandatory Palestine. London: Luzac \& Compay, Ltd.

Udat, Yacub. 1992. من أعلام الفكر والأدب في فلسطين [Scholars of Thoughts and Literature in Palestine]. Jerusalem: Dar al-Isra'.

Yāghi, Abdul-Rahman. 1966. حياة الأدب الفلسطيني الحديث [The Life of Modern Palestinian Literature]. Beirut: Dar al-Afaq, 1981.

Ziyadeh, Nicolā. 2005. الدكتور خليل طوطح مؤسس عقيدة دار المعلمين ["Dr. Khalil Tutah: The Founder of the Doctrine of the Teachers' College”]. Al-Mustaqbal 420: 8. 